\title{
Impacts of drought on water quality: the case of aquifers in eastern Algeria
}

\author{
LARBI DJABRI ${ }^{1}$, SAAD BOUHSINA ${ }^{2}$, AZZEDINE HANI ${ }^{1}$, ANTONIOPULIDO \\ BOSCH $^{3}$, JACQUES MUDRY $^{4} \&$ MOHAMED CHERIF DJOUAMAA ${ }^{5}$ \\ 1 Laboratory Water Resources and Sustainable Development. Badji Mokhtar Annaba University, Algeria \\ djabri larbi@yahoo.fr \\ 2 Department of Chemistry, Littoral Dunkerque University, France \\ 3 University of Grenada, Spain \\ 4 University of Franche Comte, France \\ 5 Badji Mohtar Annaba. University, Algeria
}

\begin{abstract}
The studied area is located in the extreme part of Algeria. It is limited to the north by the Mediterranean Sea and the desert in the south. This position confers a variation of the climatic mode, a Mediterranean climate in the north and arid in the south, resulting in a very important fall of precipitation, ranging from $1200 \mathrm{~mm} /$ year in the north, to $300 \mathrm{~mm} /$ year in the south. The hydrographic network is very dense; very important wadis (Seybouse, Mellague, Medjerda, Kebir-Are, Kebir-West) cross this area, which implies important contributions (solid and liquid). Water of aquifers is often fed by these rivers. During its displacement water acquires a certain mineralization. The studies carried out showed that this mineralization increased during recent years, thus translating the influence of the climatic factors on water quality. To explain the origin of this salinity we were interested in the climatic variations and particularly in dryness which affected the area in recent years, due to a considerable fall in the infiltrations being translated in the north by an imbalance of the interface of fresh water and salted water, generating a salinity of water. In the south the dryness accelerated water salinity. To highlight this impact several approaches were used: Statistical tool using the PCA, gives an outline on the elements at the origin of observed salinity; STUYFZAND method, based primarily on chlorides, can determine various classes of salinity; and the thermodynamic tool shows the influence of certain minerals on water salinity. The compilation of all the results enables us to conclude that the observed salinity in various zones remains influenced by the dryness.
\end{abstract}

Key words salinity; Algeria; PCA; thermodynamics; STUYFZAND

\section{INTRODUCTION}

During the last decade, climatic changes were recognized among the major obstacles with any development. Water in sufficient quantity and acceptable quality constitutes a difficult equation to solve for African countries in general, and for Algeria in particular. The requirements for water are constantly increasing, particularly for agriculture which consumes more than $87 \%$ of that available. In addition, the socio-economic development of Algeria and particularly the study area (establishments of factory site particularly consuming water and large pollutants, creation of new cities, which lets suppose many contributions out of wastewater....), resulted in a degradation of citizen life. The first report carried out shows the incidence of these climatic changes on the quality of water. This can increase the risks of pollution. It is of two forms:

- Anthropic pollution generated by the various rejections, which implies a pollution of the water resources.

- Natural pollution: the climatic changes involve a strong evaporation which results in an increase in the water salinity. This work will help us to highlight these two causes of pollution.

\section{GEOGRAPHIC SITUATION}

Figure 1 shows the studied area which covers from the west to the east, the wilayas of Skikda, Annaba, El tarf, and from the north to the south the wilayas of Guelma, Souk-Ahras and Tebessa. The studied area is limited to north by the Mediterranean Sea, in the east by the Tunisian border, to the west by the wilayas of Constantine, Batna and Oum El Bouaghi, and to the south by the wilaya of Biskra. 


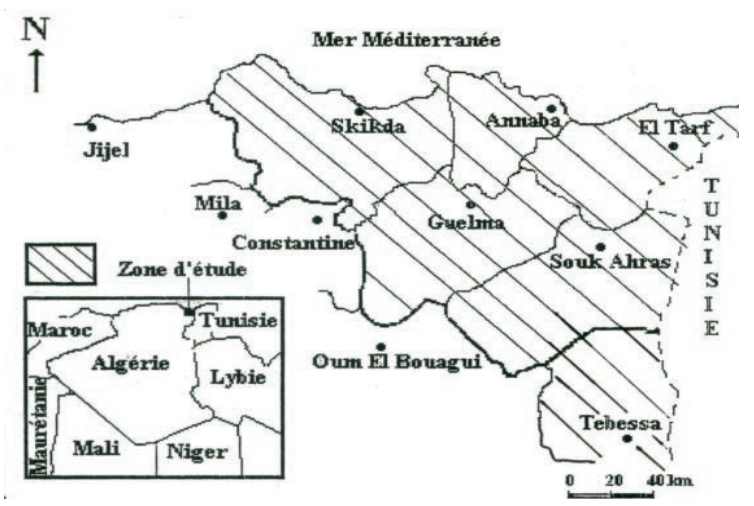

Fig. 1 Geographic situation.

\section{MATERIALS AND METHODS}

To complete this work, we combined the results obtained from several methods. As an indication, climatology informs us about the climate reigning at each station, which can establish the characteristics of each station. The geological part was studied, a particular interest was granted to the permeable formations because they are the place of all interactions and they can also contain all the aquifers described in hydrogeology. The water chemistry remains the most effective tools to highlight the relations which can exist between the parameters enumerated previously. The results obtained, starting from the carried out analyses, help us to develop the following methods:

- Principal component analysis: it makes possible to define the existing relations between the elements constituting analysed water.

- The second method used is that of STUYFZAND (1986) in El Mandour (1998); this method uses the following parameters:

Classification according to the chloride concentrations:

\begin{tabular}{llll}
\hline Main code type & Chloride $(\mathrm{mg} / \mathrm{L})$ & Main code type & Chloride $(\mathrm{mg} / \mathrm{L})$ \\
\hline Freshwater F & $<150$ & Brackish salt - water Bs & $1000-10000$ \\
Freshwater- brackish Fb & $150-300$ & Saltwater S & $10000-20000$ \\
Brackish water B & $300-1000$ & Water heavily salted H & $>20000$ \\
\hline
\end{tabular}

Classification according to the Total Hardness (TH):

\begin{tabular}{llllll}
\hline Type of water & Code & $\mathrm{TH}^{\circ} \mathrm{F}$ & Type of water & Code & $\mathrm{TH}^{\circ} \mathrm{F}$ \\
\hline Very sweet & $*$ & $<5$ & Hard & 2 & $20-40$ \\
Fresh & 0 & $5-10$ & Very hard & 3 & $40-80$ \\
$\begin{array}{l}\text { Moderately } \\
\text { hard }\end{array}$ & 1 & $10-20$ & Extremely hard & $4-9$ & $80-2560$ \\
\hline
\end{tabular}

- The chemical facies:

Code of cationic exchange: The sum of the cations $\mathrm{Na}, \mathrm{K}$ and $\mathrm{Mg}(\mathrm{meq} / \mathrm{L})$ is corrected compared to the contribution of sea water whose ratio is:

$$
\begin{aligned}
& \frac{\mathrm{Na}+\mathrm{K}+\mathrm{Mg}}{\mathrm{Cl}}=1.061 \mathrm{Cl} \\
& (\mathrm{Na}+\mathrm{K}+\mathrm{Mg}) \mathrm{C}=(\mathrm{Na}+\mathrm{K}+\mathrm{Mg}) \mathrm{m}-(1.061 \mathrm{Cl})
\end{aligned}
$$

where $c=$ corrected and $m=$ measured.

It is assumed here that all the chloride ions come from the sea; the value of the sum corrected and compared with the quantity $(0.5 \times \mathrm{Cl}), 1 / 2$ of which is a margin of error.

When the result is negative "-" often indicates a marine intrusion, when the result is zero " 0 " this indicates an equilibrium state, and when the result is positive "+", it indicates penetration of freshwater in a marine environment. 


\section{RESULTS}

\section{Geological setting}

The sedimentary formations (Fig. 2) constitute the principal outcrop in the regions of Annaba and El Tarf; they consisted of permeable formations such as sands, gravels, and of impermeable formations, particularly clays, marls, in the centre of the plains. On the edges, fissured limestones (Souk-Ahras, Tebessa, Guelma); even fissured limestones reload the aquifers. The metamorphic formations are present in the area of Annaba and consist of gneiss, mica schists, cipolins, saliferous formations are also present, particularly near Guelma, Souk-Ahras and Tebessa areas; by dissolution this formation contributes to the increase in salinity. The geological outline gives a first explanation of salinity.

Climatic characteristics The studied area is characterized by a Mediterranean climate in North, with precipitations higher than $700 \mathrm{~mm} / \mathrm{year}$; it is the case of the stations of Ain Assel $(820 \mathrm{~mm}), \mathrm{El}$ Kala $(766 \mathrm{~mm})$, Cheffia $(800 \mathrm{~mm})$, Ain El Karma $(730 \mathrm{~mm})$, the saline station $(700 \mathrm{~mm})$ and Skikda (751 mm), (Djabri 1996, Aouin Sebaiti 2010). Moving away from the sea, precipitations drop and are about $600 \mathrm{~mm}$ with Guelma and Souk-Ahras (Guasmi 2009) on the other hand with Tebessa (Ghrieb 2011), the maximum recorded is $400 \mathrm{~mm}$. Table 1 summarises the results obtained by the Thornthwaite method and shows that evapotranspiration remains important at all the stations.

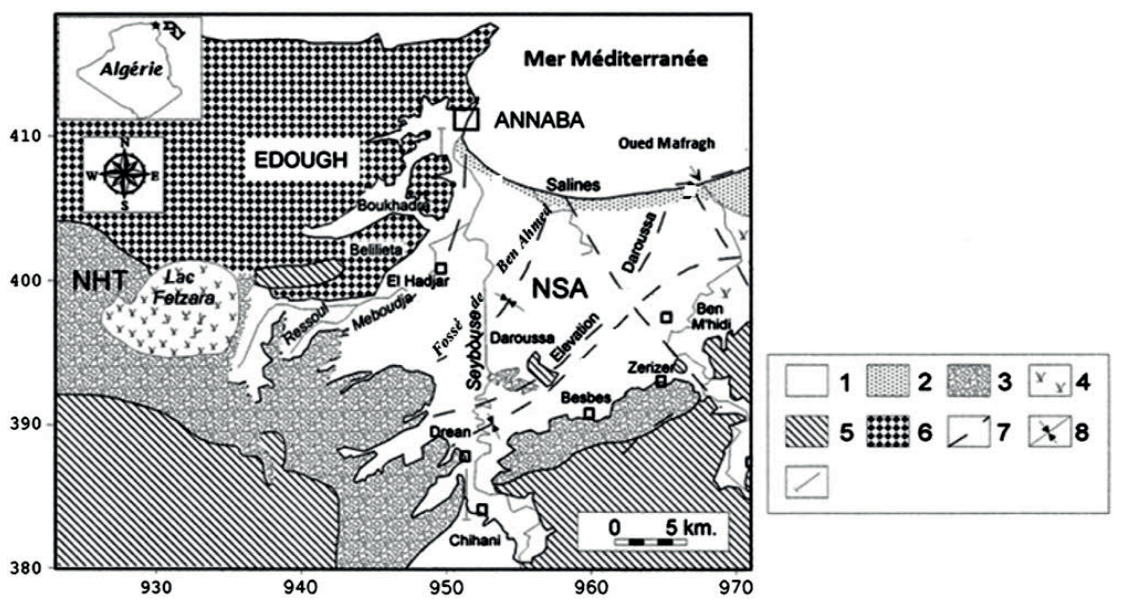

Fig.2 Geological map region Annaba-El Tarf (Aoun Sebaiti 2010). 1: Recent and actual Quaternary; 2: sandhills; 3: old Quaternary; 4: swamp or lake; 5: sandstone and Numidian clay; 6: Metamorphic formations; 7: faults; 8: trenches axis.

Table 1 Climatic characteristics of the studied area.

\begin{tabular}{lllllllllll}
\hline Characteristics & $\begin{array}{l}\mathrm{P} \\
(\mathrm{mm})\end{array}$ & $\begin{array}{l}\mathrm{Tm} \\
\left({ }^{\circ} \mathrm{C}\right)\end{array}$ & $\begin{array}{l}\mathrm{PE} \\
(\mathrm{mm})\end{array}$ & $\begin{array}{l}\mathrm{AE} \\
(\mathrm{mm})\end{array}$ & $\mathrm{Exc}$ & $\mathrm{AD}$ & $\begin{array}{l}\mathrm{R} \\
(\mathrm{mm})\end{array}$ & $\begin{array}{l}\mathrm{R} \\
(\%)\end{array}$ & $\begin{array}{l}\mathrm{I} \\
(\mathrm{mm})\end{array}$ & $\begin{array}{l}\mathrm{I} \\
(\%)\end{array}$ \\
Stations & & & & & & & & & & \\
\hline Ain Assel & 851 & 17.3 & 889.5 & 474.6 & 340.6 & 414.9 & 228.2 & 30 & 113 & 14 \\
El Kala & 765 & 18.3 & 823.8 & 513.7 & 245.9 & 310.3 & 220.1 & 29 & 131 & 16 \\
Cheffia & 785 & 16.3 & 839.5 & 495 & 320.7 & 441.2 & 210 & 27 & 116 & 15 \\
Ain Kerma & 730 & 17.3 & 889.6 & 458.3 & 271.4 & 380.4 & 163.6 & 22 & 108 & 15 \\
Salines & 686 & 18.1 & 927.9 & 445.3 & 222.3 & 471.4 & 78.7 & 11 & 162 & 24 \\
Azzaba & 649 & 18.3 & 898 & 426.5 & 222.3 & 471.4 & 54.6 & 8 & 168 & 26 \\
Skikda & 742 & 18.2 & 897 & 420 & 31.77 & 477 & 169.2 & 23 & 491 & 66 \\
Guelma & 621 & 18.1 & 1008.6 & 448 & 173.6 & 560.8 & 78.7 & 13 & 95 & 15 \\
Helliopolis & 610 & 18.1 & 889.4 & 442 & 167.7 & 457.4 & 93.3 & 15 & 74 & 12 \\
Bouchegouf & 532 & 17.8 & 925.9 & 418.4 & 113.6 & 507.5 & 58.5 & 11 & 55 & 131 \\
Taoura & 632 & 15.2 & 800 & 361.2 & 252.6 & 438.4 & 120.6 & 20 & 132 & 22 \\
Souk ahras & 611 & 15.2 & 853.5 & 404.5 & 206.4 & 448.9 & 104.4 & 17 & 102 & 17 \\
Tebessa & 354 & 15.3 & 825.2 & 319 & 35.5 & 506.3 & 21.8 & 6 & 14 & 4 \\
\hline
\end{tabular}




\section{Hydrogeological setting}

All regions are characterized by two aquifers. We take the area of EL Tarf as an example.

El Tarf Area According to the section (Fig. 3), we notice the superposition of two aquifers, one confined and the other shallow. The transmissivity varies between $1 \mathrm{E}-3$ and $2 \mathrm{E}-3 \mathrm{~m} / \mathrm{s}$, the storage coefficient is about $1.5 \mathrm{E}-3$.

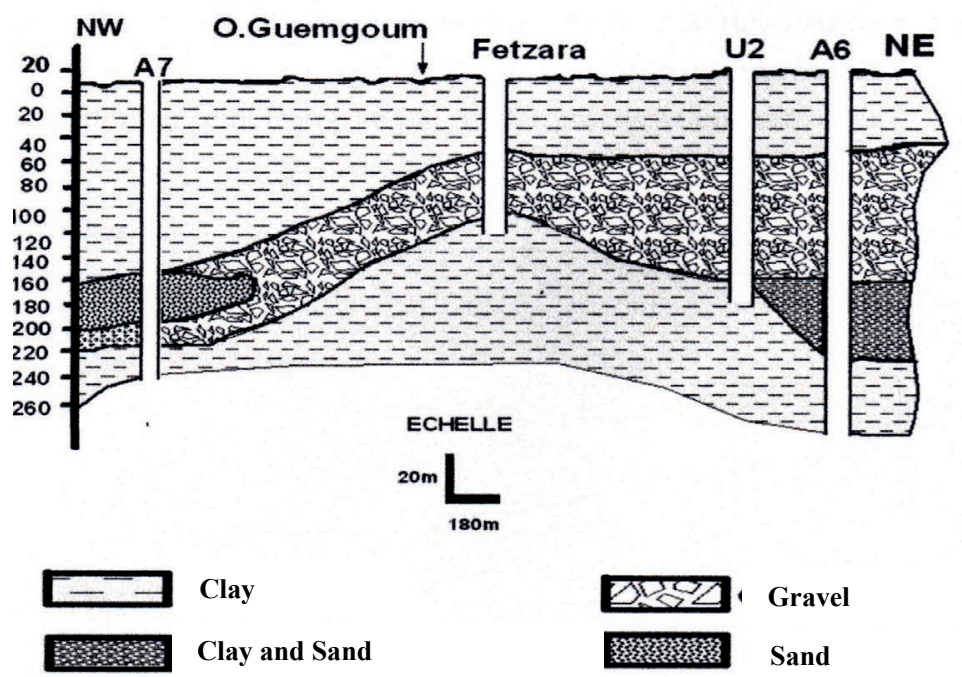

Fig. 3 Hydrogeology cross-section of Tarf area (Aoun Sebaiti Badra 2010).

Indications for groundwater salinity (Djabri 2005) To determine the problem related to the water salinity, we used several methods:

Contributions of the principal component analysis (PCA): this analysis will be carried out according to two affinities:

- a first, climatic and will include three alternatives as follows being distributed:

Mediterranean climate and will include the areas of Annaba, El Tarf and Skikda,

Areas of Guelma, Souk-Ahras and Bouchegouf, characterized by a less rainy climate,

The area of Tebessa has a semi-arid climate.

- The second alternative will take into account the outcrop of the Triassic formations:

Water of the littoral zone characterized by the absence of Sorted (Annaba, El Tarf and Skikda), The remainder of the studied part: Triassic formations are very present (Guelma, Souk-Ahras, Bouchegouf and Tebessa).

This approach will enable us to release the factors influencing the water salinity.

Table 2 Results of the principal analyses.

\begin{tabular}{|c|c|c|c|c|c|c|c|c|c|}
\hline \multicolumn{5}{|c|}{ Results obtained by using the climatic resemblances } & \multicolumn{5}{|c|}{$\begin{array}{l}\text { Results obtained according to the geological } \\
\text { distribution }\end{array}$} \\
\hline \multirow{2}{*}{$\begin{array}{l}\text { Results } \\
\text { Regions }\end{array}$} & \multicolumn{3}{|c|}{ Variances $\%$} & \multirow{2}{*}{$\begin{array}{l}\text { Variables } \\
\text { influencing } \\
\text { salinity }\end{array}$} & \multirow{2}{*}{$\begin{array}{l}\text { Results } \\
\text { Regions }\end{array}$} & \multicolumn{3}{|c|}{ Variances $\%$} & \multirow{2}{*}{$\begin{array}{l}\text { Variables } \\
\text { influencing } \\
\text { salinity }\end{array}$} \\
\hline & F1 & F2 & $(\mathrm{F} 1+\mathrm{F} 2)$ & & & F1 & F2 & $(F 1+F 2)$ & \\
\hline $\begin{array}{l}\text { Annaba } \\
\text { +Skikda + El } \\
\text { Tarf }\end{array}$ & 51.2 & 51.2 & 65 & $\mathrm{Na}-\mathrm{Cl}$ & $\begin{array}{l}\text { Annba+ } \\
\text { Skikda+ } \\
\text { El Tarf }\end{array}$ & 51.2 & 13.8 & 65 & $\mathrm{Na}-\mathrm{Cl}$ \\
\hline $\begin{array}{l}\text { Guelma } \\
\text { +Souk- } \\
\text { Ahras }\end{array}$ & 44.2 & 16.9 & 61.1 & $\mathrm{Ca}-\mathrm{Cl}$ & $\begin{array}{l}\text { Guelma+ } \\
\text { Souk-Ahras } \\
\text { +Tebessa }\end{array}$ & 47.3 & 21.4 & 68.7 & $\mathrm{Ca}-\mathrm{SO} 4$ \\
\hline Tebessa & 54.5 & 15.5 & 70 & $\mathrm{Na}-\mathrm{Cl}$ & & & & & \\
\hline
\end{tabular}


Principal component analysis by climatic affinity Table 2 summarises the principal results obtained.

The results obtained by this method are very significant; they provide more than $50 \%$ of the data in all cases.

Climatic factors, particularly evaporation remains important, which explains the appearance of $\mathrm{Ca}-\mathrm{SO}_{4}$. However, in the second alternative the dissolution of the geological formations is the only cause, either of sulfates, or of the chlorides which influence the water salinity. Their presence depends on the outcropping formations, which explain the results obtained.

\section{STUYFZAND method (1986)}

The results using the STUYFZAND method for Annaba area are given in Table 3.

Waters in their majority either are chlorinated sodic or sulfated calcic; bicarbonated water generally appears in the zones characterized by the outcrop of limestones. Water is generally hard to very hard, which indicates a high content of calcium and magnesium; they also present an oscillating principal type between $\mathrm{FB}, \mathrm{B}$, and $\mathrm{Bs}$, indicating variable water salinity.

\section{Thermodynamics}

Calculations carried out show the influence of the following minerals: anhydrite, aragonite, calcite, dolomite and gypsum. The results obtained are presented in Table 3.

Table 3 STUYFZAND Classification - Annaba area.

\begin{tabular}{|c|c|c|c|c|c|}
\hline $\begin{array}{l}\text { Analysed } \\
\text { point }\end{array}$ & $\begin{array}{l}\text { Principal } \\
\text { type }\end{array}$ & Hardness & Hardness & $\begin{array}{l}\text { Cationic } \\
\text { exchange }\end{array}$ & Chemical facies \\
\hline & & $\mathrm{TH}^{\circ} \mathrm{F}$ & Code & & \\
\hline 1 & B & 56.82 & 3 & 0 & $\mathrm{NaHCO}_{3}$ \\
\hline 2 & B & 88.5 & 4 & 0 & $\mathrm{CaCl}$ \\
\hline 3 & B & 69.6 & 3 & + & $\mathrm{NaCl}$ \\
\hline 4 & B & 70.15 & 3 & + & $\mathrm{NaCl}$ \\
\hline 5 & B & 59.6 & 3 & + & $\mathrm{NaCl}$ \\
\hline 6 & B & 77.7 & 3 & 0 & $\mathrm{NaCl}$ \\
\hline
\end{tabular}

Table 4 Saturation indices values in Gasmi (2009), Aoun Sebaiti (2010), Ghrieb (2011), Djabri et al. (2013) and Habes Sameh (2013).

\begin{tabular}{llllllllllll}
\hline Regions & $\begin{array}{l}\text { SI } \\
\text { Anhydr } \\
\text { ite }\end{array}$ & $\begin{array}{l}\text { SI } \\
\text { Aragonite }\end{array}$ & $\begin{array}{l}\text { SI } \\
\text { Calcite }\end{array}$ & $\begin{array}{l}\text { SI } \\
\text { Dolomite }\end{array}$ & $\begin{array}{l}\text { SI } \\
\text { Gypsum }\end{array}$ & Regions & $\begin{array}{l}\text { SI } \\
\text { Anhydrite }\end{array}$ & $\begin{array}{l}\text { SI } \\
\text { Aragonite }\end{array}$ & $\begin{array}{l}\text { SI } \\
\text { Calcite }\end{array}$ & $\begin{array}{l}\text { SI } \\
\text { Dolomite }\end{array}$ & $\begin{array}{l}\text { SI } \\
\text { Gypsum }\end{array}$ \\
\hline Skikda 1 & -1.5 & 1.4 & 1.5 & 3.1 & -1.3 & El tarf & -2.5 & -0.2 & -0.1 & -0.3 & -2.3 \\
$\begin{array}{l}\text { El } \\
\text { harrouch }\end{array}$ & -1.7 & -0.8 & -0.7 & -1.8 & -1.5 & Berrihane & -2.6 & 0.2 & 0.3 & 0.6 & -2.3 \\
$\begin{array}{l}\text { Skikda F } \\
\text { 195 }\end{array}$ & -1.7 & 1.2 & 1.3 & 2.7 & -1.5 & $\begin{array}{l}\text { Massif } \\
\text { dunaire }\end{array}$ & -2.6 & -1.8 & -1.7 & -3.6 & -2.4 \\
Skikda 2 & -2 & 0.7 & 0.9 & 1.3 & -1.7 & Annaba 1 & -1.4 & 0.1 & 0.3 & 0.4 & -1.2 \\
$\begin{array}{l}\text { Ramdane } \\
\text { Djamel }\end{array}$ & -1.6 & 1.8 & 1.9 & 3.7 & -1.4 & Annaba 2 & -1.5 & -0.4 & 0.1 & 0.05 & -1.2 \\
$\begin{array}{l}\text { Skikda 3 } \\
\text { Collo 7 }\end{array}$ & -1.6 & 0.7 & 0.9 & 1.5 & -1.3 & Annaba 3 & -1.5 & -1.0 & 0.07 & -0.03 & -1.3 \\
\hline
\end{tabular}

Saturation indices of anhydrite and gypsum are negative, which indicate a dissolution state between groundwater and rocks. The other minerals are sometimes positive, sometimes negative, which shows the influence of several factors on groundwater salinity. This variation varies according to precipitation, and in a rainy year an important conclusion is noted, i.e. that it causes a decrease in groundwater salinity during dry periods and that the important rate of evapotranspiration led to a high increase in concentrations and consequently an increase in salinity. 


\section{DISCUSSIONS}

The combination of several methods enabled us to highlight the impact of the climate on water quality to tackle the problem of salinity posed in the study area. The obtained results show the influence of several factors on salinity. They highlight the salinity of water in the area. The rate of salinity differs from one area to another, which explains the choice of methods used. The principal component analysis showed that the salinity of water remains much influenced by the local factors such as the climate and geology; the obtained results show a variation of the chemical elements influencing salinity between Annaba and Tébessa (extreme cities). The tests involving pumping in large amounts involve the imbalance of the interface freshwater-salt water, causing an increase in salinity; this was highlighted in the area of Annaba, El Tarf (Djabri et al. 2013).

The result obtained using the STUYFZAND method shows values of cationic exchange. This one is overall positive in the littoral zone, indicating the contribution of salt water in a freshwater environment, highlighting the influence of the sea. However, at the other zones it presents negative values, showing the water infiltration salt in a freshwater environment. This is generated by the dilution of the salt formations crossed by water. The ionic speciation and mineral dissolution/precipitation was calculated by WATEQF package software. The increase in salinity is related to the dissolution and/or precipitation processes during the water-rock interaction, and to the cationic exchange processes. These increases in salinity are accelerated by observed climatic changes, indeed the latter are at the origin of the strong evapotranspiration, which accentuates the water salinity.

\section{CONCLUSION}

The study showed that the water salinity is present. It can have several sources, which make the problem more complicated. The continuous assessment of water salinity must be systematic, because in the long run, this salinity can have harmful effects on the environment (soil, plants, water). This salinity can be caused by a sodium excess, which can involve a decrease in permeability and consequent poor irrigation of plants that die due to asphyxiation (the values of the SAR are raised by about eight in some places). To reduce this risk we recommend small hydraulics and the construction of small dams to achieve water of better quality.

\section{REFERENCES}

Aoun Sebaiti, B. (2010). Etude de l'origine de la salinité et modélisation du système aquifère de Annaba .Mémoire de Magister, Université de Annaba.

Djabri, L. (2005) Wadi water quality and patches of Eastern Algeria: Wilaya of Annaba, Skikda, El Tarf, Guelma, Souk Ahras and Tebessa. 6 international Conference - European Water Resources Association. Menton France

Djabri, L. (1996) Mécanismes de la pollution et vulnérabilité des eaux de la Seybouse. Origines géologiques, industrielles, agricoles et urbaines. Thèse de Doctorat ès-Sciences, Univ. Annaba, Algérie; $261 \mathrm{p}$.

Djabri, L. et al. (2013) Impacts of morphological factors on the marine intrusion in Annaba region (east of Algeria). Desalination and Water Treatment 2013, 1-6.

El Mandour, A (1998) Contribution to the hydrogeological study on the Triffa plain. Salinization and modelization. Doctorate Thesis, University Mohamed 1st, Department of Sciences Oujda, $185 \mathrm{p}$

Ghrieb, L. (2011) Impacts des minéralisations des formations triasiques sur la qualité des eaux de la plaine de Bekkaria (Tébessa), en zone semi Aride. Nord Est Algérien. Thèse de Doctorat de l'université d'Annaba, $180 \mathrm{p}$.

Guasmi, I. (2009) Qualité des eaux de l'oued Medjerda (Souk-Ahras). Thèse de Doctorat de l'université de Annaba. $250 \mathrm{p}$.

Habes, Sameh (2013) Caractéristiques chimiques d'un lac appartenant aux écosystèmes humides du Nord de L'Algérire. Cas du lac Fetzara Nord Est Algérien. Doctorat de l'université d'Annaba. 245 p. 